\title{
INTERAKSI SOSIAL PADA KUMPULAN CERPEN POTONGAN CERITA DI KARTU POS KARANGAN AGUS NOOR DAN IMPLIKASINYA TERHADAP PEMBELAJARAN SASTRA DI SMA
}

\author{
Rahmah Purwahida \\ Universitas Negeri Jakarta \\ E-mail: rahmah.purwahida@unj.ac.id
}

\begin{abstract}
ABSTRAK
Penelitian ini bertujuan untuk mendeskripsikan wujud dan fungsi interaksi sosial dalam keenam cerpen pada kumpulan cerpen Potongan Cerita di Kartu Pos karangan Agus Noor. Metode yang digunakan adalah metode deskriptif kualitatif dengan teknik analisis isi. Hasil penelitian ini menunjukkan bahwa: (1) wujud interaksi sosial dalam cerpencerpen pada kumpulan cerpen ini berupa interaksi sosial asosiatif dan disosiatif, interaksi sosial yang dominan yaitu interaksi sosial disosiatif; dan (2) perwujudan interaksi sosial ini berfungsi sebagai penghadiran kehidupan sosial di masyarakat dalam cerpen sebagai salah satu bentuk fiksi.
\end{abstract}

Kata kunci: wujud, fungsi, interaksi sosial, Potongan Cerita di Kartu Pos

\section{THE SOCIAL INTERACTIONS IN POTONGAN CERITA DI KARTU POS BY AGUS NOOR AND IMPLICATIONS TO LITERATURE LEARNING IN SENIOR HIGH SCHOOL}

\begin{abstract}
This research aims to describe the form and function of social interaction in six short stories called Potongan Cerita di Kartu Pos by Agus Noor. The qualitative descriptive method is used by using content analysis technique. The results show that: (1) the social interactions in short stories are associative social and dissociative social interactions, the dissociative social interaction is dominant in social interaction; and (2) the embodiment of this social interaction serves as the presence of social life in the society in short story as one of fictions form.
\end{abstract}

Keywords: form, function, social interaction, Potongan Cerita di Kartu Pos 


\section{PENDAHULUAN}

Interaksi sosial tidak dapat dihindari dalam kehidupan bermasyarakat. Melalui interaksi, manusia dapat bekerjasama, sehingga proses pencapaian tujuan hidup individu atau kelompok lebih mudah terwujud. Selain itu, interaksi juga mendorong terwujudnya pola kehidupan individu atau kelompok secara integratif, sehingga setiap individu dapat meningkatkan kualitas beragam peran sosial dalam kehidupan kelompok. Interaksi juga mendorong terbangunnya sikap mental positif pada setiap individu dalam proses-proses sosial yang dilaluinya serta mendorong lahirnya beragam inovasi di berbagai bidang sehingga membentuk peradaban. Akan tetapi, pada kenyataannya wujud interaksi sosial tidak selalu positif dan bermanfaat baik bagi pembentukan peradaban. Ada juga interaksi yang bersifat negatif dan tidak membawa manfaat bagi pembentukan peradaban.

Pendidikan sebagai salah satu jalan dan upaya pembentukan peradaban memberikan berbagai ruang untuk mengenalkan hingga memberikan pemahaman mengenai interaksi sosial kepada generasi muda penerus bangsa. Pembelajaran sastra dalam Mata Pelajaran Bahasa Indonesia di sekolah potensial sebagai jalan dan upaya mengenalkan dan memberikan pemahaman mengenai interaksi sosial karena pembelajaran sastra dapat mengadirkan karya sastra yang di dalamnya memuat cerminan kehidupan sosial di masyarakat.

Karya sastra memiliki berbagai kelebihan yang tidak dimiliki oleh sumber belajar lainnya. Karya sastra merupakan suatu bentuk dan hasil pemikiran dan perenungan serta kreativitas imajinasi yang menyikapi dan membahas manusia dan kehidupannya dengan menggunakan bahasa sebagai alat penyampaiannya. Karya sastra dapat menjelaskan kondisi manusia dengan melukiskan kehidupan pada perilaku 
manusia yang tergambar pada tokoh-tokoh yang terdapat pada karya sastra tersebut. Lebih jauh dari itu, karya sastra yang diapresiasi melalui pembelajaran apresiasi sastra dapat mengembangkan kepribadian dan memperluas pengetahuan serta wawasan siswa tentang kehidupan yang sarat dengan nilai-nilai sosial.

Salah satu faktor penting guna mewujudkan pembelajaran apresiasi sastra yang baik yaitu tersedianya materi ajar apresiasi sastra yang berkualitas. Materi ajar yang demikian hanya dapat terus disediakan dengan penelitian terhadap karya sastra yang potensial dan tepat dibelajarkan kepada siswa sesuai perkembangan psikologi siswa. Salah satu karya sastra yang diajarkan di sekolah berdasarkan Kurikulum 2013 adalah cerita pendek (cerpen). Cerpen merupakan variasi bacaan yang diharapkan mampu menarik minat siswa karena kisahnya singkat, tidak membutuhkan waktu yang lama saat membacanya, sehingga tidak membuat jenuh saat membacanya. Cerpen memungkinkan kehadiran fakta sosial dalam balutan imajinasi dan kreativitas pengarang. Hal ini dimungkinkan terjadi karena cerpen sebagai bagian dari sastra dan mempunyai potensi untuk mengungkapkan realitas sosial yang tidak bisa diungkapkan di media massa maupun media penyampaian informasi lainnya. Cerpen oleh pengarang juga digunakan untuk mengungkapkan kritik sosialnya. Kumpulan cerpen Potongan Cerita di Kartu Pos karangan Agus Noor merupakan kumpulan yang memuat cerpencerpen yang mengandung karakteristik-karakateristik tersebut.

Penelitian yang berkaitan dengan interaksi sosial dalam ranah sastra memang bukan yang pertama kali dilakukan. Sebelumnya sudah pernah dilakukan penelitian dengan judul Interaksi Sosial pada Tokoh Utama Novel Tanpa Jendela Karangan Asma Nadia dan Implikasinya terhadap Pembelajaran SMA suatu Kajian Sosiologi Sastra (Komala, 2012). Hal yang membedakan penelitian ini dengan penelitian sebelumnya 
adalah objek kajian yang digunakan. Pada penelitian terdahulu menggunakan objek kajian novel, sedangkan pada penelitian ini menggunakan objek kajian kumpulan cerpen. Selain itu, pada penelitian terdahulu hanya menganalisis hubungan-hubungan interaksi sosial pada tokoh utama, sedangkan pada penelitian ini mengkaji wujud dan fungsi interaksi sosial dalam cerpen-cerpen yang terdapat pada kumpulan cerpen Potongan Cerita di Kartu Pos sehingga penelitian ini lebih kompleks.

Endraswara (2003) mengemukakan hal-hal yang dapat menjadi tumpuan peneliti sosiologi sastra, antara lain: (a) dunia sosial dan seluk beluknya, (b) penyesuaian diri individu pada dunia lain, (c) bagaimana cita-cita untuk mengubah dunia sosialnya, (d) hubungan sastra dan politik, (e) konflik- konflik dan ketegangan dalam masyarakat. Karena penelitian ini mendeskripsikan wujud dan fungsi interaksi sosial dalam kumpulan cerpen Potongan Cerita di Kartu Pos maka tepat menggunakan pendekatan sosiologi sastra.

Gilin \& Gilin (1956) mengatakan bahwa interaksi sosial merupakan hubunganhubungan sosial yang dinamis yang menyangkut hubungan antara orang-perorangan, antara kelompok-kelompok manusia. Hubungan ini memprasyaratkan kehadiran minimal dua pihak. Interaksi akan terjadi dengan adanya kehadiran minimal dua pihak.

Koentjaningrat (1990) menambahakan bahwa interaksi sosial terjadi apabila seseorang individu melakukan sesuatu hal yang dapat menimbulkan suatu reaksi bagi individu lainnya. Rusdiyanta (2009) menegaskan pendapat kedua pakar di atas mengenai pengertian interaksi sosial sebagai hubungan pengaruh yang tampak dalam pergaulan hidup bersama.

Gilin \& Gilin (1956) menyebutkan wujud interaksi sosial: (1) proses asosiatif yang mencakup: (a) kerja sama yaitu hubungan timbal balik yang saling 
menguntungkan, (b) akomodasi yaitu suatu keseimbangan dalam interaksi antara orang perorangan atau kelompok-kelompok manusia dalam kaitannya dengan norma-norma sosial dan nilai-nilai sosial yang berlaku dalam masyarakat atau usaha-usaha untuk mencapai kestabilan, (c) asimilasi yaitu terkait erat dengan pengembangan sikap-sikap dan cita-cita yang sama, dan (2) proses sosial disosiatif yang mencakup: (a) pesaingan yaitu upaya menarik perhatian publik untuk mendapatkan keuntungan, (b) kontravensi yaitu proses sosial yang berada antara persaingan dan pertentangan atau pertikaian, dan (c) pertentangan atau pertikaian yaitu proses sosial berupa individu atau kelompok berusaha untuk memenuhi tujuannya dengan jalan menantang pihak lawan yang disertai dengan ancaman dan atau kekerasan.

\section{METODE}

Metode penelitian ini menggunakan metode deskriptif kualitatif dengan teknik analisis isi. Pendekatan kajian sastra yang digunakan yaitu sosiologi sastra. Analisis dilakukan dengan cara mengklasifikasikan data berupa kata, kelompok kata, kalimat, atau paragraf yang terdapat dalam kumpulan cerpen yang mengandung aspek-aspek bentuk interaksi sosial pada tokoh, kemudian menganalisisnya dengan pendekatan sosiologi sastra.

Objek penelitian ini adalah Potongan Cerita di Kartu Pos karangan Agus Noor, diterbitkan oleh Kompas Media Nusantara, tahun 2006. Diterbitkan dalam bentuk kumpulan cerpen setebal 173 halaman. Kumpulan cerpen ini terdiri atas sembilan cerpen. Setelah dibaca dengan cermat, maka peneliti menemukan enam cerpen yang akan menjadi bahan kajian dalam penelitian ini, yaitu (1) "Sirkus", (2) "Cerita Buat Bapak Presiden”, (3) "Pagi Bening Seekor Kupu-kupu”, (4) “Tiga Cerita Satu Tema”, 
(5) "Potongan-potongan Cerita di Kartu Pos", dan (6) "Mata Mungil yang Menyimpan Dunia".

Keenam cerpen dipilih sebagai objek dalam penelitian ini karena representatif dalam hal menghadirkan bentuk-bentuk interaksi sosial dibandingkan ketiga cerpen lainnya. Dalam ketiga cerpen yaitu "Komposisi untuk Sebuah Ilusi", Dongeng buat Pussy", dan "Puzzle Kematian Gerindra", kisah yang diceritakan pun memiliki makna yang absurd dan tidak sesuai dengan perkembangan psikologi siswa.

\section{HASIL DAN PEMBAHASAN}

Keenam cerpen dalam kumpulan cerpen Potongan Cerita di Kartu Pos karangan Agus Noor memuat wujud-wujud interaksi sosial asosiatif dan disosiatif. Proses sosial asosiatif minim karena didominasi proses sosial disosiatif. Proses sosial disosiatif ini dipicu oleh adanya ketidaktertiban sosial, sehingga keadaan ini memunculkan disintegrasi sosial akibat dari pertentangan, baik individu, kelompok, ataupun antaranggota masyarakat. Hal ini terlihat pada masalah-masalah sosial dalam keenam cerpen ini, sebagai bentuk gambaran interaksi sosial disosiatif yang banyak sekali terjadi dalam kehidupan sehari-hari baik di kota maupun di daerah. Melalui keenam cerpen ini, pengarang seolah ingin menyatakan begitu banyaknya fenomena dan masalah sosial yang bisa diangkat sebagai bentuk interaksi sosial disosiatif di dalam kehidupan bermasyarakat.

Dalam cerpen "Sirkus" tidak terdapat interaksi sosial asimilasi dan pesaingan. Interaksi sosial kontravensi dan pertikaian yang paling dominan karena cerpen ini menceritakan tentang kemiskinan dan kelaparan yang menjerat warga Flores di daerah, Nusa Tenggara Timur. Hal ini tidak terlepas dari sistem pemerintahan yang kacau. 
Sehingga warga terabaikan dari sentuhan pembangunan dari pemerintahan. Tidak hanya itu saja, pemerintah juga tidak memerhatikan nasib warga yang berada di daerah terpencil, sehingga menimbulkan masalah sosial, seperti: kerusuhan, perang saudara, rakyat kelaparan, minyak mahal, sementara orang-orang harus antre dan berkelahi untuk mendapatkan minyak, juga air bersih dan beras, pengangguran tak bisa teratasi, balita menderita kekurangan gizi, busung lapar. Tak ada yang bisa mereka makan, sebab tanah, hutan, sungai, dan teluk rusak parah tercemar limbah. Pemaparan mengenai masalah sosial ini merupakan salah satu bentuk interaksi sosial disosiatif kontravensi dengan ciri-ciri melemparkan beban pembuktian (memaparkan masalah sosial yang sedang terjadi) kepada orang lain.

Dalam cerpen "Sirkus" ditemukan bentuk interaksi sosial disosiatif kontravensi. Salah satu ciri dari kontravensi yaitu, melemparkan beban pembuktian kepada masyarakat, dengan kata lain memaparkan kepada pembaca cerpen mengai masalah sosial yang terdapat dalam cerpen ini. Berikut ini adalah kutipannya:

"Baiklah, Nak. Sudah saatnya kuceritakan rahasia ini padamu. Mereka berasal dari negeri yang telah collapse_puluhan tahun lalu. Negeri yang terus menerus dilanda kerusuhan, karena para pemimpinnya selalu bertengkar. Kerusuhan sepertinya sengaja dibudidayakan. Perang saudara meletus. Flu burung mengganas. Rakyat kelaparan_sengsara. Sementara, minyak mahal dan langka. Orang-orang harus antre dan berkelahi untuk mendapatkan minyak, juga air bersih dan beras. Pengangguran tak bisa teratasi. Otakotak balita itu menyusut. Tengkorak mereka kopong. Perut busung. Bahkan tak ada akar yang mereka makan. Sebab, tanah, hutan, sungai dan teluk rusak parah tercemar limbah. Karena tidak ada lagi yang bisa dimakan, orangorang kelaparan itu pun mulai belajar menyantap angin.

Bertahun-tahun, paru-paru dan perut mereka hanya berisi angin hingga tubuh mereka makin menggembung, seperti balon yang dipompa. Jadi begitulah, Nak. Seperti yang kau lihat di "Sirkus", mereka sesungguhnya tak bisa terbang, tapi melayang-layang karena kepala dan tubuh mereka kosong...."

(Potongan Cerita di Kartu Pos, "Sirkus", hlm. 23-24) 
Pada kutipan tersebut merupakan kategori bentuk interaksi sosial disosiatif kontravensi, dengan ciri-ciri yaitu melemparkan beban pembuktian kepada masyarakat. Dalam kutipan tersebut mendeskripsikan mengenai keadaan fisik manusia terbang yang sunggung memprihatinkan. Tubuh yang kurus, mulut yang menganga, dan kulit cokelat kusam. Dalam kutipan tersebut dipaparkan pula mengenai asal si manusia terbang dan masalah yang dihadapi si manusia terbang. Masalah-masalah sosial yang dihadapi oleh manusia terbang, antaralain: negeri yang terus menerus dilanda kerusuhan, karena para pemimpinnya selalu bertengkar. Kerusuhan sepertinya sengaja dibudidayakan. Perang saudara meletus. Flu burung mengganas. Rakyat kelaparan sengsara. Sementara, minyak mahal dan langka. Orang-orang harus antre dan berkelahi untuk mendapatkan minyak, juga air bersih dan beras. Pengangguran tak bisa teratasi. Otak-otak balita itu menyusut. Tengkorak mereka kopong. Perut busung. Bahkan tak ada akar yang mereka makan. Sebab, tanah, hutan, sungai dan teluk rusak parah tercemar limbah. Karena tidak ada lagi yang bisa dimakan si manusia terbang menyantap angin bertahun-tahun, paru-paru dan perut mereka hanya berisi angin hingga tubuh mereka makin menggembung, seperti balon yang dipompa. Keadaan manusia terbang dengan segala bentuk masalah sosial yang dihadapinya, merupakan ciri kontravensi yang melemparkan beban pembuktian kepada pihak lain untuk mengetahui persoalan sosial yang dihadapi oleh manusia terbang.

Selain bentuk interaksi sosial disosiatif kontravensi, pada cerpen "Sirkus" ini juga teradapat bentuk interaksi sosial disosiatif pertikaian. Pertikaian ini muncul disebabkan adanya bentrokan antarkepentingan, baik kepentingan ekonomi ataupun politik (kekuasaan). Hal ini terlihat pada masalah sosial yaitu kerusuhan, perang saudara, dan orang- orang harus antre dan berkelahi untuk mendapatkan minyak, juga 
air bersih dan beras. Hal inilah yang dapat menimbulkan terjadinya konflik.

Timbulnya bentuk interaksi sosial disosiatif kontravensi pada cerpen "Sirkus" ini disebabkan adanya pola disintegrasi dan ketidaktertiban sosial. Masalah sosial yang terdapat dalam cerpen ini, disimbolkan pada tokoh manusia terbang yang berasal dari Flores, Nusa Tenggara Timur. Si manusia terbang ini dijadikan sebagai alat pertunjukan dalam sebuah arena "Sirkus". Keadaan fisik manusia terbang yang memprihatinkan, seperti tubuh yang kurus, mulut yang kosong setengah terbuka, dan kulit cokelat kusam membuat para penonton merasa sedih dan iba. Keadaan fisik manusia terbang ini akibat kelaparan, sehingga bertahun-tahun paru-paru dan perut mereka hanya terisi angin hingga tubuh mereka makin mengembung dan mengembung seperti balon yang dipompa. Deskripsi keadaan fisik manusia terbang merupakan bentuk gambaran kelaparan yang luar biasa parah, karena mereka tidak bisa melakukan banyak hal, hanya bisa meratapi. Oleh sebab itu, si Gipsi tua membawa dan menjadikan manusia terbang sebagai alat pertunjukkan dalam "Sirkus", agar para penonton bisa mengetahui keadaan fisik manusia terbang akibat dari masalah sosial kelaparan. Hal ini merupakan salah satu cara si Gipsi tua untuk memaparkan masalah sosial yang dialami oelh si manusia terbang akibat dari kelaparan.

Kemudian dalam cerpen kedua yaitu "Cerita Buat Bapak Presiden” terdapat bentuk interaksi sosial disosiatif persaingan, kontravensi, dan pertentangan. Bentuk interaksi sosial disosiatif persaingan tergambar melalui tokoh Kadosta yang dicalonkan oleh warga kota sebagai pemimpin di kota itu. Pemilu merupakan bentuk interaksi sosial disosiatif persaingan, sebab berusaha untuk mendapatkan posisi kekuasaan dalam pemerintahan dengan cara menarik perhatian warga. Alasan warga kota menyalonkan Kadosta sebagai pemimpin, karena Kadosta merupakan satu- 
satunya orang yang bersedia mendengarkan keluh kesah, dan keinginan para warga kota dalam hal apa pun. Oleh sebab itu, warga merasa bahwa Kadosta adalah orang yang istimewa di kota itu. Para warga kota mendambakan pemimpin yang bersedia mendengarkan keluh kesah, harapan, dan keinginan warga. Dengan terpilihnya Kadosta sebagai pemimpin warga sangat senang sebab segala macam persolan, keluh kesah kesah, dan keinginan warga dapat didengarkan oleh Kadosta. Cerita dalam cerpen ini merupakan bentuk cerminan dan kritikan sosial kepada pemerintah yang enggan sekali mendengar keluh kesah rakyat. Masalah seperti ini umum terjadi baik di kota besar amaupun daerah.

Bentuk interaksi sosial disosiatif yang lain pada cerpen ini yaitu kontravensi dengan ciri melemparkan beban pembuktian (memaparkan masalah sosial) kepada orang lain. Hal ini terlihat pada keadaan udara kota yang mulai terasa gerah, jalanan yang rusak berlubang-lubang, saluran air yang mampet, pohon-pohon yang ditebang secara sembarangan, keadaan kota yang semerawut, gubug-gubug liar makin menjalar, bangunan-bangunan liar yang membuat kota semakin sesak, serta uang sogokan di bawah meja. Keadaan sosial seperti ini merupakan masalah sosial kemiskinan, ekonomi, dan politik yang banyak terjadi di kehidupan bermasyarakat. Ciri lain dari bentuk interaksi sosial disosiatif pada cerpen "Cerita buat Bapak Presiden" adalah mengecewakan warga kota. Terpilihnya Kadosta sebagai pemimpin membuat warga kota menyambut gembira atas kemenangan Kadosta sebagai pemimpin di kota itu. Warga kota sangat senang karena segala macam cerita, keluh kesah, dan keinginan warga dapat dengan mudah diceritakan kepada Kadosta. Akan tetapi, keadaan seperti ini tidak berlangsung lama, karena Kadosta merasa kewalahan dan kesal terhadap sikap warga. Menurut Kadosta, sebaiknya warga kota dapat menyelesaikan 
masalahnya sendiri tanpa harus selalu bercerita kepada Kadosta untuk bisa didengarkan dan ditanggapi. Perubahan sikap Kadosta yang seperti itu membuat warga kota merasa kecewa, sebab warga kota kehilangan sosok pemimpin yang senantiasa bersedia mendengarkan cerita, keluh kesah, dan harapan warga.

Terdapat bentuk interaksi sosial disosiatif pertikaian dalam cerpen ini, pertikaian yang terjadi dalam cerpen ini mengenai pembunuhan misterius yang dilakukan oleh sekelompok orang yang berseragam. Adanya pembunuhan besarbesaran yang terjadi di kota, tentu disebabkan adanya pertentangan kepentingan antar golongan mengenai sesuatu hal.

Pertikaian terjadi disebabkan oleh adanya pertentangan antara pihak lawan, baik individu ataupun kelompok dengan cara menantang pihak lawan yang disertai dengan kekerasan. Hal inilah yang menimbulkan terjadinya konflik, ketika masingmasing pihak berinteraksi untuk saling menghancurkan, menyingkirkan, dan mengalahkan karena alasan bentrokan antar kepentingan, rasa benci, dan permusuhan.

\section{Mereka tak pernah mau mempercakapkan ribuan warga yang diculik segerombolan berseragam, dibawa ke kebun karet, kemudian dihabisi dengan serentetan tembakan. Sebagian lagi, mati digantung atau dibuang ke jurang. Saat itu, di kota kami sepertinya ada hantu palasik yang siap menghisap otak orang yang masih saja suka kasak-kusuk melakukan percakapan. (Potongan Cerita di Kartu Pos, "Cerita Buat Bapak Presiden”, hlm. 32)}

Bentuk interaksi sosial disosiatif pada kutipan cerita tersebut yaitu pertikaian, hal ini ditunjukkan melalui adanya pembantaian. Di kota itu suatu ketika pernah terjadi kerusuhan. Para warga kota merasa ketakutan atas kejadian kerusuhan yang berakibat pembunuhan, atas kejadian ini maka warga kota tidak pernah ada yang berani untuk membicarakan tentang hal ini. Warga kota terbiasa diam ketika terjadi banyak kejanggalan. Bentuk interaksi sosial disosiatif lainnya, yaitu kontavensi, karena ada 
pihak-pihak atau orang-orang yang menggosipkan peristiwa pembantaian tersebut, sehingga dapat dikatakan bahwa kontavensi pada kutipan tersebut merupakan pemicu terjadinya pertikaian.

Cerpen ketiga "Pagi Bening Seekor Kupu-kupu" terdapat bentuk interaksi sosial disosiatif kontravensi. Tokoh anak kecil laki-laki yang berteman dengan seekor kupukupu. Kedua tokoh utama ini banyak menghabiskan waktunya untuk bercerita, dan bermain bersama di taman. Hingga pada suatu waktu, si bocah laki- laki ini bercerita kepada si kupu-kupu mengenai kesedihan hatinya, ia tidak bisa menikmati keceriaan sebagai seorang anak kecil seperti bermain, dan bersekolah. Ia hanya hidup sebagai anak jalanan yang ditinggal mati oleh ibunya, dan memiliki ayah yang pengangguran, gemar mabuk, dan memukuli dirinya. Sehingga untuk mencukupi kebutuhan sehari-hari si bocah ini harus bekerja di pabrik sebagai pengepak kardus pada malam hari. Maka tidaklah mengherankan jika ia ingin sekali menjelma sebagai seekor kupu-kupu, supaya bisa terbang dan merasakan kebebasan, tidak ada tekanan hidup. Keadaan yang dialami oleh si bocah laki-laki itu, merupakan bentuk deskripsi pemaparan masalah sosial kemiskinan dan ekonomi, atau dengan kata lain melemparkan beban pembuktian kepada orang lain mengenai masalah yang dialaminya. Sang ayah yang selalu memukuli bocah tersebut, terlebih lagi saat si bocah laki-laki pulang ke rumah tidak membawa uang, maka sang ayah akan semakin kalap untuk menganiaya, dan melontarkan makian serta kata-kata kasar. Tindakan kekerasan yang dilakukan oleh tokoh ayah merupakan bentuk interaksi sosial pertikaian, dan kontravensi dengan ciri-ciri membentak (mencerca) dengan menggunakan kata- kata kasar sebagaimana tergambar dalam kutipan berikut ini.

Ia merasakan ketakutan yang luar biasa, ketika laki-laki itu mencekik lehernya. "Uang!' bentak laki-laki itu. 
"Mana uangnya?! Brengsek!"

"Berapa kali aku bilang, kamu jangan pulang kalau gak bawa uang!"

(Potongan Cerita di Kartu Pos, "Pagi Bening Seekor Kupu- kupu", hlm. 54)

Cerpen keempat "Tiga Cerita Satu Tema" bercerita mengenai seorang pembunuh bayaran. Tugas utamanya adalah membunuh oknum-oknum tertentu yang diperintahkan atasannya. Seperti, saat tokoh utama yang berperan sebagai pembunuh bayaran harus membunuh tokoh oposisi, aktivis pergerakan, istri seorang pejabat, membunuh dan menculik mahasiswa, serta seorang pengusaha. Tindakan semacam ini merupakan bentuk interaksi sosial disosiatif pertikaian. Sebab dalam hal ini terlihat adanya pertentangan atau perbedaaan kepentingan antargolongan. Sehingga menyebabkan terjadinya konflik. Dalam cerpen ini juga diceritakan saat terjadi kerusuhan dan bentrokan antara mahasiswa dan polisi, tindakan seperti juga merupakan bentuk interaksi sosial disosiatif pertikaian, Mahasiswa tidak menyetujui kenaikan harga BBM dan sistem pemerintahan yang dirasa tidak memihak rakyat malah justru merugikan, sehingga mahasiswa berdemonstrasi untuk berunjuk rasa (menyampaikan bentuk protesnya kepada pemerintah) akan tetapi, berakhir dengan kerusuhan, dan bentrokan. Terjadinya peristiwa ini menyebabkan keadaan kota tidak aman, dan penjarahan di mana- mana. Pada saat inilah pembunuh bayaran ditugaskan untuk melenyapkan nyawa orang-orang yang dianggap membahayakan kepentingan orang tersebut. Hal tersebut sebagaimana tergambar dalam kutipan berikut ini.

"Kamu punya bakat bagus. Percuma kalo jadi tentara. Paling kamu mentok jadi sersan", kata Komandan.

Lalu sepulang perang, ia diberinya pekerjaan. Pekerjaan yang tak terlalu sulit, cuma menghabisi istri seorang pejabat, karena pejabat itu ingin kawin lagi.

Lalu beberapa pekerjaan ringan lainnya. menculik beberapa mahasiswa, membunuh seorang pengusaha, membakar pasar yang hendak direnovasi, menghabisi seorang wartawan. Ia menikmati bayaran yang lumayan. Benar kata komandannya. Penghasilan pembunuh bayaran lebih baik ketimbang gaji sersan.

(Potongan Cerita di Kartu Pos, “Tiga Cerita Satu Tema”, hlm. 105) 
Sistem pemerintahan yang tidak memihak kepada rakyat, seperti era reformasi kemudian, keputusan pemerintah yang juga tidak memihak rakyat, seperti kenaikan BBM membuat para mahasiswa berdemonstrasi. Aksi demontrasi tersebut merupakan salah satu bentuk interaksi sosial disosiatif kontravensi, dengan ciri-ciri memberikan perlawanan terhadap sistem dan putusan pemerintahan yang tidak memihak rakyat.

Cerpen kelima "Potongan-Potongan Cerita di Kartu Pos" menceritakan tentang tokoh Maiya yang memiliki kalung manik-manik. Kalung manik-manik itu terbuat dari tetesan airmata. Tetesan airmata berasal dari tetesan airmata bayi- bayi yang lahir sekarat, ibu-ibu yang tak bisa lagi menyusui karena air susu mereka kering, dan busung lapar. Kemudian tangis itu mengeras dalam kepahitan hidup orang-orang yang tinggal di perkampungan kumuh. Perlahan-lahan tangisan dari orang-orang tersebut mengristal menjadi butiran airmata. Dengan menjual manik-manik airmata itu orang-orang tersebut bisa bertahan hidup. Keadaan sosial yang memprihatinkan seperti itu merupakan bentuk interaksi sosial disosiatif kontravensi, yaitu melemparkan beban pembuktian (memaparkan masalah sosial) kepada orang lain. Airmata dalam cerpen ini merupakan simbolisasi atas ketidakberdayaan rakyat dalam menghadapi kemiskinan dan kelaparan. Mereka harus bisa bertahan hidup, di tengah keterpurukan keadaan ekonomi yang kian sulit.

Cerpen keenam "Mata Mungil yang Menyimpan Dunia” menceritakan tentang tokoh Gustaf yang ingin sekali mempunyai mata yang indah. Gustaf menganggap bahwa mata bocah yang tengah bermain-main di kolong jalan layang adalah mata yang begitu indah. Gustaf selalu memandangi bocah tersebut. Rambutnya kusam kecokelatan karena panas matahari, bercelana pendek kucel, berkoreng di lutut kirinya. Bocah tersebut tidak berbeda dengan anak jalanan lainnya yang makin hari makin 
bertambah jumlahnya. Di mata bocah tersebut, Gustaf seperti melihat dunia yang menyegarkan. Dunia yang tenang bening terbentang dalam mata mungil bocah itu. Keinginan Gustaf untuk memiliki mata tersebut, maka Gustaf menculik bocah itu kemudian mengganti matanya dengan mata bocah tersebut. Hal ni sebagaimana tergambar dalam kutipan berikut ini.

Apa pun akan Gustaf lakukan agar ia bisa memiliki mata itu. Bila perlu ia menculiknya. Terlalu banyak anak jalanan berkeliaran, dan pastilah tak seorang pun yang peduli bila salah satu dari mereka hilang. Gustaf tersenyum. Ia sering mendengar cerita soal operasi ganti mata. Ia tinggal datang ke Medical Eye Centre untuk mengganti matanya dengan mata bocah itu! (Potongan Cerita di Kartu Pos, "Mata Mungil yang Menyimpan Dunia, hlm. 172)

Hal ini tentu saja bertentangan dengan hati nuraninya. Adanya bentuk pertentangan yang terjadi dalam diri Gustaf yaitu timbulnya kepentingan pribadi untuk memeroleh mata bocah tersebut. bentuk interaksi sosial disosiatif pada cerpen ini adalah pertentangan. Bentuk interaksi sosial disosiatif jenis lainnya adalah kontravensi, yaitu melemparkan beban pembuktian (memaparkan keadaan atau masalah sosial) kepada orang lain, seperti bertambahnya jumlah anak jalanan. Kedaan semacam ini merupakan salah satu masalah sosial sebagai akibat dari kemiskinan dan rendahnya taraf ekonomi masyarakat kelas bawah. Jika dibiarkan secara terus menerus maka tingkat pendidikan pun menjadi sangat rendah.

Berdasarkan penelitian bentuk-bentuk interaksi sosial disoiatif dalam perihal bentuk-bentuk interaksi sosial disoisatif pada tokoh utama dalam kumpulan cerpen Potongan Cerita di Kartu Pos karangan Agus Noor, dapat diperoleh implikasi penelitian. Adapun dalam implikasinya enam cerpen ("Sirkus", "Cerita buat Bapak Presiden”, "Pagi Bening Seekor Kupu-kupu”, “Tiga Cerita Satu Tema”, "Potonganpotongan Cerita di Kartu Pos", dan "Mata Mungil yang Menyimpan Dunia") dalam 
kumpulan cerpen Potongan Cerita di Kartu Pos dapat menjadi salah satu alasan serta alternatif untuk menambah minat siswa untuk menelaah cerpen secara mendalam. Cerpen-cerpen tersebut dapat pula menambah kemauan serta kemampuan siswa dalam mempelajari cerpen-cerpen yang berkisar pada bentuk-bentuk interaksi sosial disosiatif yang terjadi dalam kehidupan bermasyarakat.

Cerpen-cerpen yang bermuatan sosial dalam kumpulan cerpen Potongan Cerita di Kartu Pos dapat dipelajari di SMA, khususnya kelas X dan XI SMA, mengenai kehidupan bermasyarakat dan kegiatan berinteraksi dengan lingkungan sekitar sampai timbulnya permasalahan dalam kehidupan sosial pada tokoh utama. Berkaitan dengan hal itu, para guru Bahasa Indonesia dan siswa SMA, khususnya kelas X dan XI SMA yang memelajari cerpen dapat berupaya memecahkan perihal-perihal terkait bentuk interaksi sosial disosiatif tokoh utama. Pemecahan tersebut dapat dilakukan melalui analisis unsur intrinsik berupa tokoh, perwatakan, plot, dan latar, serta melalui analisis bentuk interaksi sosial disosiatif yang terdiri atas: persaingan, kontravensi, dan pertentangan atau pertikaian.

\section{KESIMPULAN}

Hasil penelitian kumpulan cerpen Potongan Cerita di Kartu Pos karangan Agus Noor, meliputi enam cerpen yaitu: (1) "Sirkus", (2) "Cerita buat Bapak Presiden”, (3) "Pagi Bening Seekor Kupu-Kupu”, (4) “Tiga Cerita Satu Tema”, (5) "Potongan-Potongan Cerita di Kartu Pos", (6) "Mata Mungil yang Menyimpan Dunia”, dapat ditarik kesimpulan bahwa: (1) wujud interaksi sosial dalam cerpencerpen pada kumpulan cerpen ini berupa interaksi sosial asosiatif dan disosiatif, interaksi sosial yang dominan yaitu interaksi sosial disosiatif; dan (2) perwujudan 
interaksi sosial ini berfungsi sebagai penghadiran kehidupan sosial di masyarakat dalam cerpen sebagai salah satu bentuk fiksi.

\section{UCAPAN TERIMA KASIH}

Terima kasih kepada berbagai pihak yang mendukung pelaksanaan penelitian ini.

\section{DAFTAR PUSTAKA}

Gilin, J. L \& Gilin, J.P. (1956). A cultural sociology: A revision of an introduction to sosiology. New York: Macmillan.

Komala, H. (2012). Interaksi sosial pada tokoh utama novel Tanpa Jendela karangan Asma Nadia dan implikasinya terhadap pembelajaran SMA suatu kajian sosiologi sastra. Jakarta: Galang Press.

Rusdiyanta, S.S. (2009). Dasar-dasar sosiologi. Yogyakarta: Graha Ilmu.

Koenjtaningrat. (1990). Pengantar ilmu antropologi. Jakarta: Rineka Cipta.

Endraswara, S. (2003). Metode penelitian sastra. Yogyakarta: Pustaka Widyatama. 